\title{
SYSTEMATIC DIFFERENCES OF RETAIL EXCHANGE RATE SPREADS IN SOME EU COUNTRIES: THE BANKS AGAINST FINANCIAL INTEGRATION
}

\author{
Enn Listra, Katrin Rahu, Niina Vaiser \\ Tallinn University of Technology
}

\begin{abstract}
An important policy goal in European Union has been integration of markets and economic convergence. The aim of this exploratory paper is to study pricing of currency exchange services based on bid-ask spreads in commercial banks and the policy implications of the delayed integration of banking markets. The currency rate spreads in different bank groups and countries are compared with each other. The main results of the study are that statistically significant differences exist in the spreads set by banking groups in different countries. All banking groups in the sample offer more favorable rates in Western countries indicating that the pricing policy of bank groups may be discriminatory. Further research is needed to understand the extent and the mechanism of it and to determine which policy measures may help to overcome the problem.
\end{abstract}

Keywords: policy, convergence, integration of markets, international business, commercial banking, currency rates, spreads, pricing

JEL Classification: G21, M16, M31

\section{Introduction}

The main objects of research of this paper the retail currency exchange rates and their spreads in commercial bank groups both in Western and Eastern Europe. It will be shown that in contrary of the EU level integration policy banks keep at least the retail currency markets of countries separated from each other. The area of the study is relatively unexplored despite the fact that enormous amount of literature exists on the related fields of research.

The study is based on the premise that the retail rates are determined by two groups of factors: by underlying macroeconomics influencing bank units in a country in a similar way and by the internal policies of banking MNC-s that may or may not be discriminatory. The creation of Euro area has certainly helped integrating the financial sector but the retail banking has been seen as less integrated among other markets (Vajanne, 2007, p.7) that is in correlation with the results of this study.

The convergence of financial sector in EU has been subject to number of studies but surprisingly, the currency rates that the banks charge and pay their customers have almost left out of the interest by academic researchers and the retail exchange rates per se of commercial banks have not been studied much. The main focus has been on studying exchange rates on the country level and on the interbank market. The situation is understandable if one takes into account fact that only about $5 \%$ of 
currency market is connected to economic needs of agents and remaining $95 \%$ is driven by speculative motives (Krishnan et al, 2009). Example topics of the research on influence of currency rates on economy are relationship between trading volumes and rates' volatility (Bjønnes et al, 2005) and relationship between currency rates and stock prices (Stavarek, 2004).

The authors study retail currency exchange rate spreads from a viewpoint of nonfinancial firms. The present paper is an attempt to uncover some regularity in international banking setting and to describe the differences in exchange rates between banks in Eastern and Western Europe. The actuality of the topic derives from the fact that the full integration of financial sector is not achieved even in monetary terms and the expansion of the euro-zone is still in process. One aim of the process is also to achieve better integration of banking services market.

The aim of this exploratory paper is to study pricing of currency exchange services based on bid-ask spreads in commercial banks and the policy implications of the delayed integration of banking markets. Authors suggest that exchange rates in banks of Western Europe are more favorable for clients than in Eastern Europe. To reach the aim following main research questions were kept in mind:

1) to explore the pattern of behavior of different banking units inside of same countries;

2) to compare retail currency spreads of the same banking group units in different countries;

3) to compare aggregated behavior of MNC banking units in different parts of European Union.

The study is mainly exploratory and is the first stage of a research program. Section 3 of the study gives overview of the sample of model and of data. The limitations that derive from data collection process are discussed and data and data sources are described in this section. The section 4 begins with the overview of the methodology of comparison. The results of comparison of banks in the countries under study are described in subsection 4.2. The question do different banking units inside a particular country have similar or diverging pattern of behavior is studied here. The in-group comparison of banking units of different countries is described in subsection 4.3. Main research question to be answered is how different is the behavior of banking units of the same banking groups in different countries. Section 5 deals with the comparison of currency rate spreads in the banks of groups of countries dealing with aggregated differences on the level of country groups. The paper ends with discussion of results and conclusions.

\section{Overview of related literature}

Extensive literature on the interbank currency exchange market exists today with detailed studies on the influences of different factors on the currency rates and currency rate spreads. The main findings have long quoted even in textbooks "spreads on the interbank market are based on the breadth and depth of a market for a given currency as well as on the currency's volatility" (Clark, Levesseur, et. al., 
1993, p. 147). Levi (1990, p. 37) mentions without further discussion that banks charge their customers more than interbank ask rate and pay less than bid rate and that the size of the spread depends mainly on the volume of retail transactions. Lyons (1995) finds that inventory risk is main determinant of currency rate quoted spreads.

Currency rates became important object of research after the breakdown of the Bretton Woods fixed-parity system both because of monetary policy considerations and because of the needs of international financial management in MNCs (Multinational Corporations). The research on the relationship between exchange rates and (goods) prices has been developing rapidly during recent decades (Menon, J., 1995; Goldberg and Knetter, 1997). Either exchange rate pass-through (Goldberg and Knetter, 1997) or the pricing-to-market as termed by Krugman (1987) are main strands of literature.

Studying financial integration in Europe Pichler, Steiner et al (2008) mention that "integration and the single market for financial services per se are the ultimate objective of the EU's integration efforts". Faruqee (2007) defines that "financial integration can be viewed as a multidimensional process, in which a system of financial markets becomes more closely interrelated over time in terms of its (1) market organization and infrastructure, (2) rules and regulations, and (3) pricing, transactions, and market practices." While Horobet, Joldes et al (2008) find some exchange rate convergence in Central and Eastern Europe, our findings contradict to these results in retail markets.

Our study is focused on the question of integration of markets in pricing. Possible price discrimination is one of research questions in this study. It is well know that if international bank groups have certain degree of monopoly power in their markets then they can increase the profit discriminating against the customers in a particular country of operations (Hill, 2009).

An important flow of related literature is connected with foreign exchange rate exposure (Muller and Verschoor, 2006) that is partly determined by the behavior of commercial banks. The fact that belonging to Euro area is not distinguishing with respect of exposure to foreign exchange risk (Bartram and Karolyi, 2006; Hutson and O'Driscoll, 2010) allows to study Euro area and non-Euro area banks together.

Deeper analysis of determination of spreads is given by market microstructure theory that counts three or four components for the spreads: inventory risk, operating costs (and profit margin), monopoly power, and adverse selection (Huang and Stoll (1997), Harris (2003)). Monopoly power is frequently excluded in currency microstructure literature (Rime, (2003)). Two important results from this literature apply to our study. The spread is dependent upon the type of client (Fan and Lyons, 2003) and upon the level of activity (order flow) influences the size of the spread (Osler, 2006). Based on this result we divide research object and consider in our study separately the big (GBP, JPY, USD) and the small currencies (NOK, SEK, DKK, CHF). 


\section{The sample}

Authors used daily exchange rates quoted by sample banks during the period January-March 2010. For the comparison, the differences (spread) from the daily exchange rates of European Central Bank were calculated for all the banks' retail currency rates being compared. The comparison was made between banks in two countries from Eastern Europe and two countries from Western Europe using seven currencies: CHF, DKK, GBP, JPY, NOK, SEK and USD.

Seemingly, the potential data set may be enormous. Closer inspection shows that only few banks can easily be incorporated into this study and sample selection is influenced by availability of data. Main problems are:

1) many banks have subsidiaries or branches in Eastern Europe but only few of them in Western Europe;

2) homepages of the majority of Western banks are uninformative about currency rates;

3) only selected retail currency rates are public in majority of banks;

4) banks frequently publish the spot rates but do not publish the time series of the rates on their homepages.

According to European Banking Federation statistics (2010) Germany has Europe's largest banking sector and represents with Austria banking environment in Western Europe. Czech Republic and Poland represent Eastern Europe. In all cases the headquarters are located in the West and daughter companies are in the East. These four countries were chosen because of the geographic and economic closeness. If the integration is present it should be most developed in the case of these Central European countries. If not, the convergence policy has not created its results yet.

Four international banking groups were chosen into sample - Unicredit Bank, Erste Group, Raiffeisen Bank, and Commerzbank (called Unicredit, Erste, Raiffeisen, and Commezbank in following sections and Tables for simplicity). Each of these banks runs business at least in two of sample countries and each of countries is represented by two banking units from different bank group.

Unicredit Bank Czech Republic that belongs to the Unicredit Group with Italian roots (History of the Group, 2010) is a universal bank that offers services both to private persons and firms (About us, 2010). The data were drawn from Unicredit Bank Czech Republic complete Exchange rates (2010). Another bank is Česká Sporitelna that belongs to Erste Group since 2000 (Erste Group, 2010) and the data are obtained from Česká Spořitelna exchange rates (2010).

Poland is represented by BRE Bank and Raiffeisen Bank Polska S.A. (70\% of BRE Bank's shares are owned by Commerzbank). Data were obtained from BRE Bank exchange rates (2010). Raiffeisen Bank Polska S.A data were obtained from Exchange Rates of Raiffeisen Bank Polska S.S. (2010). 
From Austria Raiffeisen Zentralbank Österreich and Erste Group were included into sample. The data for Raiffesen come from Raiffeisen währungen (2010). Erste Bank's data come from Erste Bank Market Overview: Currencies (2010).

HypoVereinsbank (HVB) and Commerzbank are the two banks from Germany. HVB belongs to the Unicredit Group (Strategy, 2010) and will be called Unicredit below for clarity reasons. Te data come from Commerzbank Devisen-Marktkurse (2010) and from HypoVereinsbank Währungen (2010).

The country-bank pairs in sample are illustrated in the Table 2. It was also the aim was to create a symmetric group of sample banks when the data choices were made.

The data set contains altogether approximately 6950 retail currency rate values. Two types of currencies were chosen for study to control possible size effects based on the results of order-flow literature of market microstructure above. "Big" currencies are GBP, USD, and JPY. "Small" currencies are CHF, DKK, SEK, and NOK. As a benchmark, currency rates quoted by European Central Bank were used throughout the study. The data come from European Central Bank Euro foreign exchange reference rates (2010).

Table 1. Average spreads and coefficients of variation of daily spreads (standard deviation divided by average spreads; in brackets, \%, January-March 2010)

\begin{tabular}{|l|l|l|l|l|l|l|l|l|}
\hline Bank & CHF & DKK & GBP & JPY & NOK & SEK & USD & Average \\
\hline Poland Raiffeisen & $\begin{array}{l}3,152 \\
(16)\end{array}$ & $\begin{array}{l}3,143 \\
(16)\end{array}$ & $\begin{array}{l}3,151 \\
(18)\end{array}$ & $\begin{array}{l}3,156 \\
(18)\end{array}$ & $\begin{array}{l}3,084 \\
(18)\end{array}$ & $\begin{array}{l}3,135 \\
(19)\end{array}$ & $\begin{array}{l}3,176 \\
(16)\end{array}$ & $(17,4)$ \\
\hline Poland & 2,942 & 2,771 & 2,436 & 2,84 & 2,743 & 2,775 & 2,488 & $(13,0)$ \\
Commerzbank & $(11)$ & $(11)$ & $(16)$ & $\begin{array}{l}(18) \\
(10)\end{array}$ & $(10)$ & $(16)$ & \\
\hline Czech Erste & 1,796 & 1,835 & 1,838 & 1,729 & 1,765 & 1,761 & 1,749 & $(27,2)$ \\
& $(19)$ & $(16)$ & $(27)$ & $(51)$ & $(20)$ & $(21)$ & $(36)$ & \\
\hline Czech Unicredit & 1,983 & 2,012 & 2,014 & 1,962 & 1,921 & 1,938 & 1,767 & $(23,5)$ \\
& $(17)$ & $(14)$ & $(25)$ & $(39)$ & $(18)$ & $(19)$ & $(34)$ & \\
\hline Austria Erste & 0,500 & 0,376 & 0,314 & 0,526 & 0,338 & 0,359 & 0,340 & $(35,4)$ \\
& $(14)$ & $(2)$ & $(55)$ & $(51)$ & $(42)$ & $(37)$ & $(48)$ & \\
\hline Austria Raiffeisen & 0,186 & 0,015 & 0,393 & 0,629 & 0,248 & 0,327 & 0,430 & $(74,34)$ \\
& $(88)$ & $(121)$ & $(58)$ & $(68)$ & $(73)$ & $(55)$ & $(57)$ & \\
\hline Germany & 0,197 & 0,272 & 0,299 & 0,353 & 0,302 & 0,275 & 0,367 & $(51,44)$ \\
Unicredit & $(35)$ & $(4)$ & $(65)$ & $(81)$ & $(56)$ & $(64)$ & $(55)$ & \\
\hline Germany & 0,137 & 0,268 & 0,205 & 0,189 & 0,245 & 0,227 & 0,201 & $(54,79)$ \\
Commerzbank & $(41)$ & $(3)$ & $(72)$ & $(106)$ & $(50)$ & $(47)$ & $(64)$ & \\
\hline
\end{tabular}

Source: authors' calculations.

The analysis was carried out based on differences of bid currency rates and those of Central Banks (spreads). First, the currency rates of non-Euro countries were transformed to Euro bases using the local Central Bank's Euro versus home currency rates. Second, to make all data comparable the spreads with ECB rates 
were calculated. Actual comparison of banks and countries was made using these spreads.

As a first step of the study average spreads and the coefficients of variation (standard deviation divided by average value of corresponding spreads) for the sample were calculated for all spreads over banks, countries and currencies (Table 1). One can easily verify that there are systematic differences in the behavior of bank units.

\section{In-country and in-group comparison of currency rate spreads 4.1. Methodology of comparison}

In Table 2 the country and bank pairs are given to form the bases for analysis. The analysis is carried out for 7 currencies (CHF, DKK, GBP, JPY, NOK, SEK, USD).

Table 2. Countries and Bank Groups in sample

\begin{tabular}{|l|c|c|c|c|}
\hline & Unicredit & Erste Group & Raiffeisen & Commerzbank \\
\hline Czech Rep. & $\mathrm{X}$ & $\mathrm{X}$ & & \\
\hline Austria & & $\mathrm{X}$ & $\mathrm{X}$ & \\
\hline Poland & & & $\mathrm{X}$ & $\mathrm{X}$ \\
\hline Germany & $\mathrm{X}$ & & & $\mathrm{X}$ \\
\hline
\end{tabular}

Source: author's illustration.

Based on the daily time series (January - March, 2010) of retail currency rates average spreads were found for all banks and currencies. The analysis and comparison of banks is based on these averages. To control for statistical significance of findings the Student's t-test was used with confidence level of 0,05 (the results given in Table 4). The in-country, in-group, and between countries comparison was based on the time series of differences of spreads that were found as a differences of corresponding larger and smaller spreads quoted by units of comparison.

\subsection{In-country comparison}

The currency rates in the same country are driven by same factors except in-group policy factors. In this subsection we compare behavior of banks with the aim to uncover differences of spreads of different banking groups operating in same environment. It is clear from data presented here that the different banks' views on suitable currency rates in the same country differ from each other considerably but the differences remain smaller compared to the differences between countries as we will see later in this paper. Some differences of banks decisions seem to derive from the different policies of bank groups towards their group units in different locations but the question of the policies remains out of scope of this paper.

In Czech Republic the sample banks Unicredit and Erste were compared with each other. Unicredit's spreads are larger in the case of all currencies in sample as can be 
evidenced on the Figure 1. The spread is the largest for GBP $(2,014 \%)$ and the smallest for USD $(1,767 \%)$ in Unicredit. Erste's the largest spread is also for GBP $(1,838 \%)$ and the smallest for JPY $(1,729 \%)$. The spreads' differences are statistically significant only in the cases of "small" currencies (Table 4).

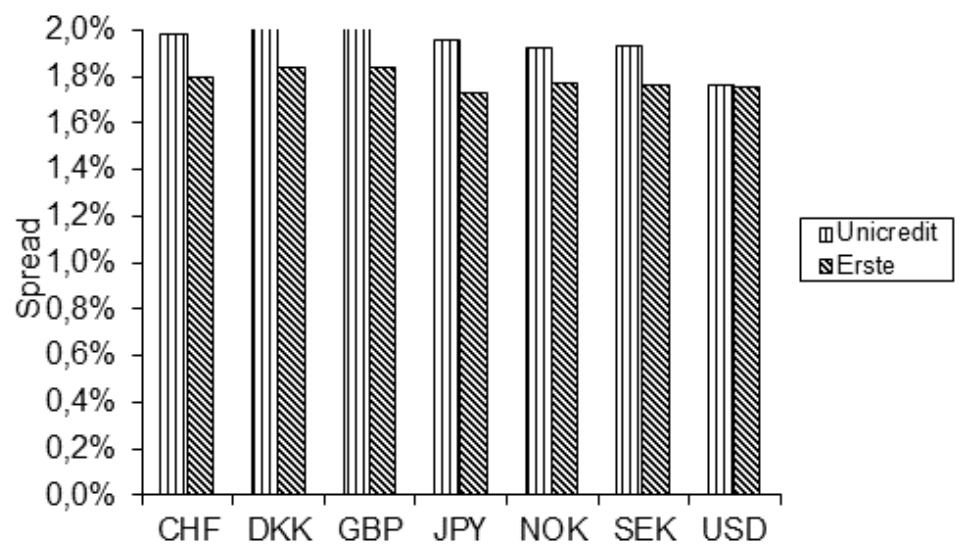

Figure 1. Comparison of average spreads in Czech banks. Source: authors' illustration.

In Poland the retail currency rate spreads quoted by sample banks are very similar to those in Czech Republic. In all cases the spread is larger in one bank, Raiffeisen, but the differences of spreads are larger compared to the case of Czech Republic (Table $3)$. In Raiffeisen the spread is the largest for USD rates $(3,177 \%)$ and the smallest for NOK rates (3,085\%). Commerzbank's the largest spread is for CHF $(2,94 \%)$ and the smallest for GBP $(2,436 \%)$. The differences are statistically significant for all currencies (Table 4).

Table 3. Differences of average spreads from ECB rates

\begin{tabular}{|l|l|l|l|l|}
\hline & Czech Rep. & Austria & Poland & Germany \\
\cline { 2 - 5 } & $\begin{array}{l}\text { Unicredit- } \\
\text { Erste }\end{array}$ & $\begin{array}{l}\text { Raiffeisen- } \\
\text { Erste }\end{array}$ & $\begin{array}{l}\text { Commerzbank- } \\
\text { Raiffeisen }\end{array}$ & $\begin{array}{l}\text { Commerzbank- } \\
\text { Unicredit }\end{array}$ \\
\hline CHF & 10,4 & 169,5 & 7,2 & 43,9 \\
\hline DKK & 9,6 & 2433,5 & 13,4 & 1,5 \\
\hline GBP & 9,6 & $-20,1$ & 29,3 & 45,6 \\
\hline JPY & 13,4 & $-16,4$ & 11,1 & 86,8 \\
\hline NOK & 8,9 & 36,3 & 12,5 & 23,3 \\
\hline SEK & 10,1 & 9,7 & 13,0 & 21,1 \\
\hline USD & 1,0 & $-20,9$ & 27,7 & 82,6 \\
\hline
\end{tabular}

Source: authors' calculations. 
The pattern of the spreads is very different in the case of Austrian banks when compared to Eastern European countries (Figure 3). The spreads in Austria are distributed unevenly with Erste having larger spreads in the case of 4 currencies and Raiffeisen in the case of 3 currencies. Also the level of spreads is smaller having the maximum below $0,65 \%$. Both banks have their largest spreads in the case of JPY (Raiffeisen - 0,629\% and Erste - 0,526\%). Erste's the smallest spread is for GBP $(0.314 \%)$ and Raiffeisen's the smallest spread for DKK $(0,015 \%)$. Except JPY and SEK the differences of average spreads are statistically significant (Table 4).

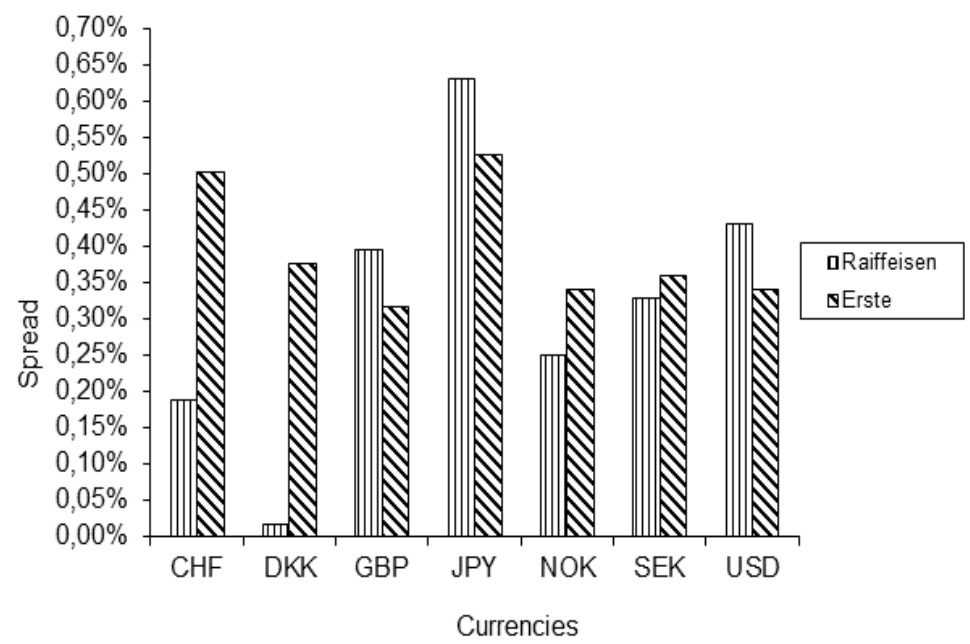

Figure 2. Comparison of average spreads in Austrian banks. Source: authors' calculations and illustration.

The spreads in Germany are distributed unevenly as in Austria but the level of spreads is lower. However, the spreads are larger in Unicredit for all currencies in sample. The largest spread in Unicredit is for USD $(0,367 \%)$ and in Commerzbank for DKK $(0,268 \%)$. The spread is the smallest in Unicredit for CHF $(0,197 \%)$ and in Commerzbank also for CHF (0,137\%). Except of NOK and SEK, all differences are statistically significant (Table 4 ).

The results of pair wise comparison (statistical significance) are described in Table 4. The reasons for such results are not clear but it seems of importance for future research that in the case of smallest banking sector (Czech Republic) the differences were not significant for the big currencies and that in the case of biggest banking sector (Germany) in the sample the differences were not significant only for the two small currencies.

The different distributions of spreads over currencies in different country groups cannot be explained by macroeconomic factors and they exist due to the in-group policies. The bank groups tend to have different policies towards their customers in 
Eastern and Western Europe. The contents of these policies remain out of scope of this study but they can exist only if these markets are separated and the customers cannot take advantage of the arbitrage opportunities.

Table 4. Statistical significance of differences of spreads (95\% confidence)

\begin{tabular}{|l|l|l|l|l|}
\hline & Czech Rep. & Austria & Poland & Germany \\
\cline { 2 - 5 } & $\begin{array}{l}\text { Unicredit- } \\
\text { Erste }\end{array}$ & $\begin{array}{l}\text { Raiffeisen- } \\
\text { Erste }\end{array}$ & $\begin{array}{l}\text { Commerzbank- } \\
\text { Raiffeisen }\end{array}$ & $\begin{array}{l}\text { Commerzbank- } \\
\text { Unicredit }\end{array}$ \\
\hline CHF & + & + & + & + \\
\hline DKK & + & + & + & + \\
\hline GBP & - & + & + & + \\
\hline JPY & - & - & + & + \\
\hline NOK & + & + & + & - \\
\hline SEK & + & - & + & - \\
\hline USD & - & + & + & + \\
\hline
\end{tabular}

Source: authors' calculations, results of Student's t-test.

\subsection{In-group comparison between countries}

If price discrimination is present in our data it could be evidenced by comparison of behaviour of the subunits of same banking group in different countries. The research objective in this subsection is to compare behavior of the same bank group units acting in different countries with the aim to understand whether the spreads are mainly determined by the membership in a group or the spreads are depending on the fact that they are located in a particular country. In all cases one banking unit compared is the Western mother bank and the other is the Eastern daughter bank. The literature review indicated that the difference may be considerable.

The units of Unicredit group in our sample are located in Germany and in Czech Republic. The comparison (Table 1) shows that the levels of spreads in these countries are considerably different over the countries but very similar over the currencies under study. In Germany the spreads are between $0,19 \%-0,4 \%$ and in Czech Republic between 1,8\%-2,1\%. The differences of spreads are distributed evenly (Table 5).

Another comparison was made between units of Erste in Austria and Czech Republic. The pattern is very similar to the previous one. In Austria the spreads were between 0,31\% - 0,53\% and in Czech Republic between 1,72\% - 1,84\%.

Comparison of units of Commerzbank in Poland and Germany lead to conclusion that in Germany the spreads are $0,13 \%-0,27 \%$ being more evenly distributed compared to Poland $(2,4 \%-3,0 \%)$.

The analysis of data from Raiffeisen group gave similar results compared to those above. In Austria the spreads are between $0,01 \%-0,63 \%$ being relatively most 
volatile in the whole sample. In Poland the spreads are more evenly distributed and are between $3,08 \%-3,18 \%$.

Table 5. Comparison of differences (\% points) of average spreads from ECB rates

\begin{tabular}{|l|l|l|l|l|}
\hline & Unicredit & Erste & Commerzbank & Raiffeisen \\
\cline { 2 - 5 } & $\begin{array}{l}\text { Germany- } \\
\text { Czech Rep. }\end{array}$ & $\begin{array}{l}\text { Austria- } \\
\text { Czech Rep. }\end{array}$ & $\begin{array}{l}\text { Germany- } \\
\text { Poland }\end{array}$ & $\begin{array}{l}\text { Austria- } \\
\text { Poland }\end{array}$ \\
\hline CHF & 1,79 & 1,30 & 2,81 & 2,97 \\
\hline DKK & 1,74 & 1,46 & 2,50 & 3,13 \\
\hline GBP & 1,72 & 1,52 & 2,23 & 2,76 \\
\hline JPY & 1,61 & 1,20 & 2,65 & 2,53 \\
\hline NOK & 1,62 & 1,43 & 2,50 & 2,84 \\
\hline SEK & 1,66 & 1,40 & 2,55 & 2,81 \\
\hline USD & 1,40 & 1,41 & 2,29 & 2,75 \\
\hline
\end{tabular}

Source: authors' calculations.

The results of this section indicate again that all bank groups in the sample have different policies towards their Western and Eastern customers.

\section{Comparison of countries and country groups}

To finalize our analysis the spreads are compared by countries. We compare the spreads quoted by the banks' units in two pairs of similar countries and also between the country groups (Eastern Europe and Western Europe) in this section. The section ends with the comparison of all bank groups and countries to control the transitivity of spreads over the sample.

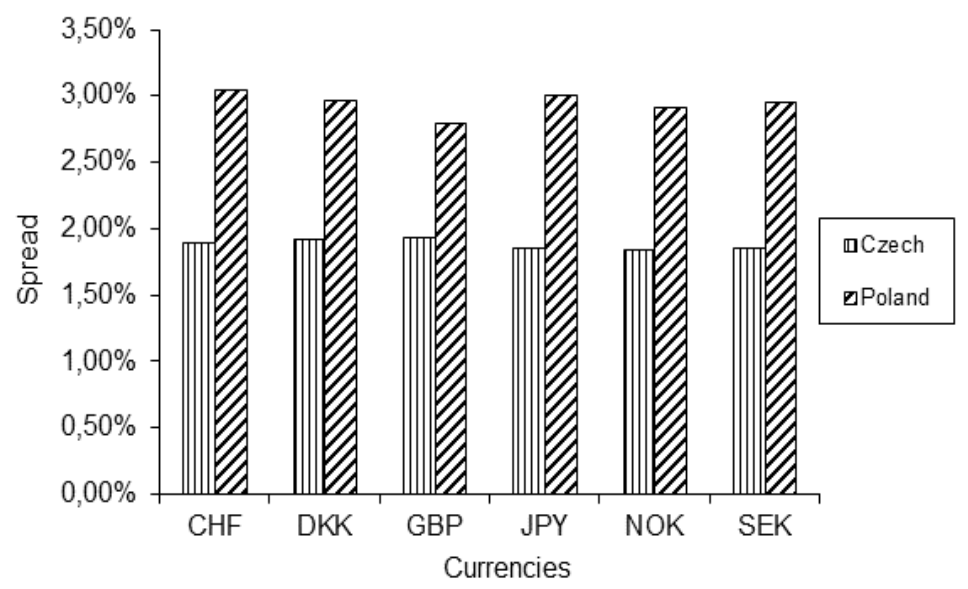

Figure 3. Average spreads in the sample from Czech Republic and Poland. Source: authors' calculations and illustration. 
First we compare the spreads quoted by banks of sample in Czech Republic and Poland. The spreads are calculated based on currency rates of local central banks (National Bank of Poland fixing, 2010 and Selected exchange rates ..., 2010) instead of ECB. It is clear from Figure 3 that in all cases the spreads are larger in Poland. Differences of the spreads are statistically significant. Czech spreads remain in interval 1,7\% - 2\% and in Poland the spreads are between 2,8\% - 3\%.

The distribution of the spreads in the case of Austria and Germany (Figure 4) is different compared to the Eastern countries. First, Germany's spreads are distributed more evenly and Austria's ones are more volatile. The volatility over different currencies is considerably higher in relative terms in Western Europe and the levels of spreads are lower compared to those in Eastern Europe indicating once more that banks have different policies depending on the country of location.

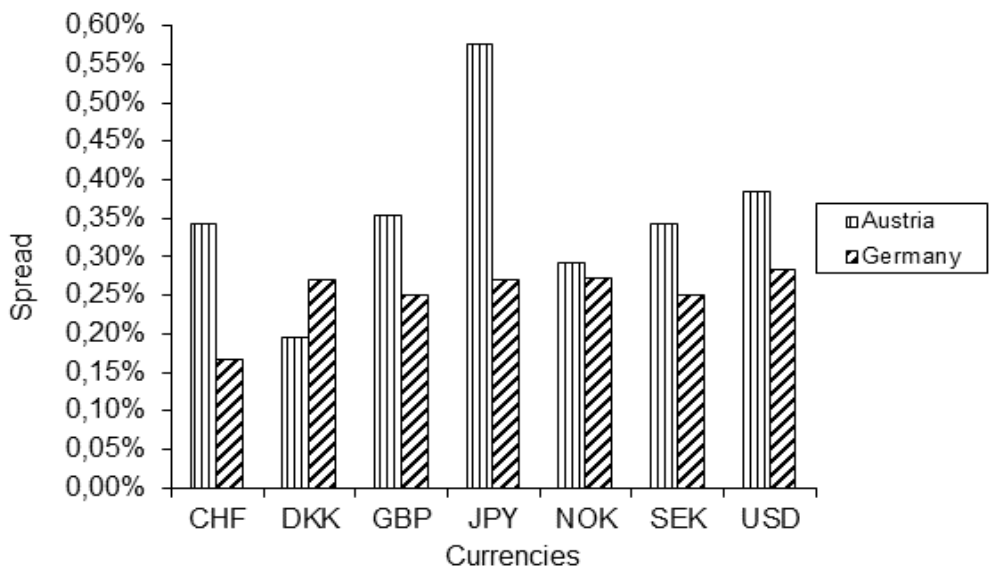

Figure 4. Average spreads in the sample from Austria and Germany. Source: authors' calculations and illustration.

The difference of spreads in two groups of countries is very large - spreads in Eastern Europe are higher (Table 6) compared to spreads in Western country. Relative volatility over currencies is higher in Western countries.

Considerably lower spreads and higher relative volatility over currencies in Western units of bank groups indicates that in-group policy rules that apply to the units in the West and in the East are as a rule different in the groups under study.

Findings above do not depend on the size. However, bank groups do handle the small and the big currencies differently as expected based on the results of the earlier literature about the influence of order-flow. 
Table 6. Average spreads from ECB currency rates in Eastern and Western Europe sample banks (January-March 2010, \%)

\begin{tabular}{|l|l|l|l|l|l|l|}
\hline & $\begin{array}{l}\text { Czech } \\
\text { Rep. }\end{array}$ & Poland & $\begin{array}{l}\text { Eastern } \\
\text { Europe }\end{array}$ & Austria & Germany & $\begin{array}{l}\text { Western } \\
\text { Europe }\end{array}$ \\
\hline CHF & 1,890 & 3,047 & 2,469 & 0,343 & 0,167 & 0,255 \\
\hline DKK & 1,924 & 2,957 & 2,441 & 0,195 & 0,270 & 0,233 \\
\hline GBP & 1,926 & 2,794 & 2,360 & 0,354 & 0,252 & 0,303 \\
\hline JPY & 1,846 & 2,998 & 2,422 & 0,578 & 0,271 & 0,424 \\
\hline NOK & 1,843 & 2,914 & 2,378 & 0,293 & 0,274 & 0,283 \\
\hline SEK & 1,849 & 2,955 & 2,402 & 0,343 & 0,251 & 0,297 \\
\hline USD & 1,758 & 2,832 & 2,295 & 0,385 & 0,284 & 0,335 \\
\hline
\end{tabular}

Source: authors' calculations.

\section{Conclusions}

The objective of the paper was to explore the extent of fulfilling the integration policy goal in European banking market. In the case of full integration of the market customers of banks should get similar services with similar prices not depending on which part of market (country) they are located. Using data provided on homepages of banking groups the study was carried out in retail currency exchange sector where the services are most uniform.

The aim of this paper is achieved comparing the behavior towards their currency exchange customers of different banking groups having business in Eastern and Western Europe. As the bases for comparison the retail currency exchange rate spreads were used. Under the constraint of data availability a symmetric sample of four countries (Austria, Czech Republic, Germany and Poland) and of four international banking groups (Unicredit, Erste, Commerzbank and Raiffeisen) was formed with the headquarters located in Western Europe and all banks having business in two countries of the sample.

The average retail currency exchange rate spreads were compared among the banking units and countries to uncover the banks' units' behavioral patterns. The prices (here spreads) for similar services should be same in all parts of the market in the case of fully integrated markets. If the prices (spreads) are discriminatory, there is a need to further integrate the markets and to set specific policy goals.

Main results of the study were following:

1) In-country comparison of the banking units belonging to different MNC-s (banking groups) showed that the pattern of spreads was similar inside a country. The statistically significant differences existed but not in all cases of currency-country pairs;

2) In-group comparison of retail currency spreads showed that in all cases banking groups offer more favorable terms to their Western customers (the spreads in Western banking units were lower compared to their Eastern 
counterparts. In all cases the differences of spreads were statistically significant and larger compared to in-country differences);

3) The determination of the spreads in Western banking units seems to be based on discretion and in Eastern banking units it seems to be rule based over the currencies; considerable differences in volatility over currencies in East and West indicate that in the Eastern European banking units the decisions seem to be based on the groups' policy rule and in the Western banking units the decisions are more discretionary;

4) The comparison of aggregated data by countries showed that the differences of spreads offered by these international banking groups were much more different between the Western-Eastern country pairs compared to EasternEastern and Western-Western pairs.

5) Differences in exchange rates between Eastern and Western Europe within chosen countries are very significant. It was found that exchange rates in Western Europe are more favorable for all analyzed currencies in the case of all analyzed banks.

The results are contradicting to the frequent assumption made in currency market microstructure literature (Rime, 2003) that monopoly power should be excluded as a factor determining the spreads. The results show that in case of retail market the assumption is most probably not correct and the theory should be improved to fit the reality of retail markets.

All results of the study above indicate that commercial banks' in-group policies may be discriminatory and the integration of banking markets at least in retail currency exchange area is not achieved. Anecdotal evidence exists, supporting the idea that banks may even act contrary to attempts of overall European policies of markets' integration.

Special policy measures should be designed to overcome the problem and to prevent the banks using discriminatory pricing inside of the European Union market.

\section{References}

1. About us. [WWW] http://www.unicreditbank.cz/en/about-the-bank.html (14.03.2010).

2. Bartram, S. M., and Karolyi, G. A. (2006). The impact of the introduction of the Euro on foreign exchange risk exposure. Journal of Empirical Finance 13, pp. $519-549$.

3. Bjønnes, G.H., Rime, D., Solheim, H.O.Aa. (2005). Volume and volatility in the foreign exchange market: Does it matter who you are? In Paul DeGrauwe (ed), Exchange rate economics. Where do we stand? Cambridge and London: MIT Press.

4. BRE Bank exchange rates. [WWW] http://www.brebank.pl/en/economic_review/Rates_and_Quotations/bre_bank_ex change_rates/ (05.03.2010). 
5. Česká Spořitelna exchange rates. [WWW] http://www.csas.cz/banka/appmanager/portal/banka;JSESSIONID_internet $10=\mathrm{s}$ nSQLHgh1Jp8JQvTyWmkvGr7yrtyWm28w51vB6TD7JlkSZ3YQZDJ!1286837434 ? $\mathrm{nfpb}=$ true\& pageLabel=exchangerates $(05.03 .2010)$.

6. Commerzbank. Devisen-Marktkurse. [WWW] https://www.commerzbank.com/de/hauptnavigation/kurse/kursinfo/devisenk/tae gl_devisenk/taegl_devisenk.html (05.03.2010).

7. Erste Bank. Market overview: Currencies. [WWW] http://produkte.erstegroup.com/Retail/en/MarketsAndTrends/Currencies/Sites/E B Fixings and Downloads/Exchange rates/index.phtml (05.03.2010).

8. Erste Group. [WWW] www.erstegroup.com (15.03.2010).

9. European Banking Federation statistics. [WWW] http://www.ebffbe.eu/index.php?page=statistics (16.03.2010).

10. European Central Bank. Euro foreign exchange reference rates. [WWW]http://www.ecb.int/stats/exchange/eurofxref/html/index.en.html (05.03.2010).

11. Exchange rates of Raiffeisen Bank Polska S.A. [WWW] http://www.raiffeisen.pl/\#/serwis-ekonomiczny?ulang=en (03.05.2010).

12. Fan, M., and Lyons, R. K. (2003). Customer Trades and extreme events in foreign exchange. In Paul Mizen (ed.), Monetary History, Exchange Rates and Financial Markets: Essays in Honour of Charles Goodhart, Northampton: Edward Elgar, pp. 160 - 179.

13. Faruqee, H. (2007). Key Concepts, Benefits, and Risks. In Fonteyne, W., Decressin, J., and Faruqee,H (eds). Integrating Europe's financial Markets. Washington DC, US: International Monetary Fund.

14. Goldberg, P. K., and M. K. Knetter. (1997). Goods Prices and Exchange Rates: What Have We Learned? Journal of Economic Literature, 35, pp. 1243 72.

15. Harris, L. (2003). Trading and Exchanges: Market Microstructure for Practitioners. New York: Oxford University press

16. Hill, Charles W. L. (2009). International Business: Competing in the Global Marketplace. New York: McGraw-Hill/Irwin.

17. History of the group. [WWW] http://www.unicreditbank.cz/en/about-thebank/unicredit-group.html (14.03.2010).

18. Horobet, A., C. Joldes, et al. (2008). "Exchange Rate Convergence in Central and Eastern Europe: A Cluster-Based Approach." Integrative Relations between the European Union Institutions and the Member States, Vol 3, pp. 202-210.

19. Huang, R. D., and Stoll, H. R. (1997). The components of bid-ask spread: A general approach. Review of Financial Studies 10, pp. $995-1034$.

20. Hutson, E., and O'Driscoll, A. (2010). Firm-level exchange rate exposure in the Eurozone. International Business Review 19, pp. $468-478$.

21. HypoVereinsbank Währungen. [WWW] http://www.hypovereinsbank.de/portal?view=/privatkunden/exchangeRatesHisto ric.jsp (27.04.2010).

22. Krugman, P. (1987). Pricing to market When Exchange Rate Changes, in Sven W. Arndt and J. David Richardson (eds.), Real Financial Linkages Among Open Economies. Cambridge, MA: MIT Press, pp. $49-70$. 
23. Levi, M. D. (1990). International finance, 2nd ed. New York: McGraw-Hill.

24. Levi, M. D. (2005). International finance, 4th ed. New York: Routledge.

25. Lyons, R. K. (1995). Tests of Microstructural Hypotheses in the Foreign Exchange Market. Journal of Financial Economics, 39, pp. 321-351.

26. Menon, J. (1995). Exchange Rate Pass-Through. Journal of Economic Surveys 9 , pp. $197-231$.

27. Moore. P. (2009) Opportunity knocks but will Germany's banks answer? http://web.ebscohost.com (26.03.2010).

28. Muller, A., and Verschoor, W. F.C. (2006). Foreign exchange risk exposure: Survey and suggestions. Journal of Multinational Financial Management, 16, pp. $385-410$.

29. National Bank of Poland fixing [WWW] http://www.brebank.pl/en/economic review/Rates and Quotations/nbp fixing/? chart $=$ true \& $\operatorname{code}=$ EUR (03.05.2010).

30. Osler, C. (2006). Macro Lessons from Microstructure. International Journal of Finance and Economics 11 , pp. $55-80$.

31. Pichler, A., Steiner, K., Fink, G, and Haiss, P. (2008). Financial Integration in Europe: Effects on Markets and Economic Growth. Services Liberation in the Internal Market, 6, pp. 167-227-

32. Raiffeisen again recognized as „Best Bank in Central and Eastern Europe“ by Global Finance. [WWW] http://www.ri.co.at/index.php?id=33\&L=1\&tx_ttnews[pS]=1272914277\&tx_ttn ews[tt_news] $=865 \&$ tx_ttnews[backPid] $=1 \& \mathrm{cHash}=2133408024(04.05 .2010)$

33. Raiffeisen währungen. [WWW] http://www.raiffeisen.at/eBusiness/ rai_template1/1006637000974-1006622505728_149330541554906331149330541554906331-NA-1-NA.html (28.04.2010).

34. Rime, D. (2003). New Electronic Trading Systems in Foreign Exchange Markets. In The New Economy Handbook. USA, Elsevier Science, pp. $469-$ 504.

35. Selected exchange rates of Czech National Bank [WWW] http://www.cnb.cz/en/financial_markets/foreign_exchange_market/exchange_rat e fixing/selected form.jsp (03.05.2010).

36. Stavarek, D. $(20 \overline{0} 4)$. Stock prices and exchange rates in the EU and the USA: evidence of their mutual interactions. [WWW] http://mpra.ub.unimuenchen.de/7297/ (24.02.2010).

37. Strategy. [WWW] http://profile.hypovereinsbank.de/cms/profile/strategy/index.html (05.05.2010)

38. UniCredit Bank Czech Republic complete exchange rates. [WWW] http://www.unicreditbank.cz/en/complete-exchange-rates.html (05.03.2010).

39. Vajanne, L. Integration in euro area retail banking markets - convergence of credit interest rates. Bank of Finland Research Discussion Papers 27/2007. 